\title{
Effect of Organic Selenium and Lycopene Addition of A Diet Enriched with Flaxseed Oil on Performance, Carcass, Blood Lipid Profile, Lipid Traits in The Muscle and Antioxidant Property of Rabbits
}

\author{
H. S. Zeweil, S. M. Zahran, M. H. Ahmed, Y. El- Gindy and A. A. Laftah \\ Department of Animal and Fish Production, Faculty of Agriculture (Saba Basha), \\ Alexandria University.
}

\begin{abstract}
The present study aimed to investigate the performance development, antioxidative status, immunological effects, muscle $n-3$ and $n-6$ fatty acids resulting from supplemented the flaxseed oil diets of growing V-line rabbits with lycopene and / or organic selenium during Egyptian summer season. Sixty growing V-line rabbits of both sexes, 5 weeks old, with initial weights of $781.0 \pm 23.85 \mathrm{~g}$ were used for the study. The rabbits were randomly allocated to five treatments groups of 12 rabbits each. Each treatment was further sub-divided into 4 replicates of 3 rabbits. Group I - fed a pelleted basal diet with standard components (control group), group II - fed a pelleted diet with $2 \%$ flaxseed oil, group III - fed a pelleted diet with $2 \%$ flaxseed oil and $0.25 \mathrm{mg} / \mathrm{kg}$ diet organic selenium Sel-plex, group IV - fed a pelleted diet with $2 \%$ flaxseed oil and $110 \mathrm{mg}$ lycopene/ $\mathrm{kg}$ diet, group VI - fed a pelleted diet with $2 \%$ flaxseed oil plus $0.25 \mathrm{mg} / \mathrm{kg}$ diet organic selenium Sel-plex® and $110 \mathrm{mg}$ lycopene/ $\mathrm{kg}$ diet. The results showed that different experimental treatments had insignificant effect on growth performance and carcass traits. Serum total lipids, total cholesterol and low density lipoprotein significantly $(P \leq 0.05)$ decreased due to different experimental diets, however, high density lipoprotein concentration and HDL/LDL ratio were significantly $(P \leq 0.05)$ increased in comparison with the control group. Exposing growing rabbits to high temperature conditions during summer season resulted in significant decrease $(P \leq$ $0.001)$ in serum total antioxidant capacity and elevated $(P \leq 0.05)$ serum malondialdehyde (MDA) which was obtained in the control group, however, including flaxseed oil or flaxseed oil plus different feed additives used in the present study appeared to antagonize the effect of high temperature during summer. The $n-3$ fatty acids were significantly $(P \leq 0.05)$ increased by feeding flaxseed oil, flaxseed oil plus organic selenium, flaxseed oil plus $110 \mathrm{mg}$ lycopene and mix of flaxseed oil plus organic selenium and $110 \mathrm{mg}$ lycopene treatments, while the $\mathrm{n}-6$ fatty acids were increased significantly by feeding flaxseed oil plus organic selenium, flaxseed oil plus $110 \mathrm{mg}$ lycopene and mix of flaxseed oil plus organic selenium and $110 \mathrm{mg}$ lycopene treatment. In conclusion, the addition of flaxseed oil with organic selenium or lycopene could be recommendable to increase n-3 polyunsaturated fatty acids (PUFA) in rabbit meats, providing a healthier and functional rabbit meat to consumer.
\end{abstract}

\section{INTRODUCTION}

Flax is flowering plants native to the Mediterranean and to Central Asian areas but has been introduced to North America possibly as a weed in flax. It cultivated as an oilseed crop to produce vegetable oil and animal feed. The crop is now being researched due to its nutritional characteristics. It is seed has an oil content that about $40 \%$ on a dry matter basis (Budin et al., 1995) Flaxseed oil is a rich source of the flowing unsaturated fatty acids: oleic $20 \%$, linoleic $24 \%$ and linolenic acid $42 \%$ (Flachowsky et al., 1998). And it has a relative low content of glucosinolates (Schuster and Friedt, 1998), but, PUFA-enriched meat could be more susceptible to oxidation especially heat stress. Tomatoes and related tomato products are the major source of lycopene in the human diet. Marković et al. (2006) 
reported that lycopene is an acyclic carotenoid and contains 11 conjugated double bonds. In nature, most carotenoids originally occur in the all-trans forms. Lycopene, with its acyclic structure, large array of conjugated double bonds, and extreme hydrophobicity, exhibits many unique and distinct biological properties. Lycopene provided strong protection against singlet oxygen-induced cell damage with the use of an in vitro studies. Lycopene is extraordinarily efficient in the control of degenerative diseases; it is a preventive against cardiovascular diseases and cancer of the prostate gland, digestive tract, skin, pancreas and uterine uvula. Lycopene also blocks the biosynthesis of cholesterol. Lycopene is a potent antioxidant that provides protection against cellular damage caused by reactive oxygen species. Lycopene has an effective free radical scavenging activity, and this action could be beneficial to rabbits and poultry because harmful free radicals are formed under the stress, fast growth, high reproduction rates and intensive metabolism conditions of poultry farming. Lycopene may play an important role in the antioxidant defense system (Ševčíková et al., 2008). Several studies confirmed many positive effects of organic selenium including immune response, lipid peroxidation, and antioxodative properties. The importance of selenium in animal nutrition lies in the fact that both first and second levels of antioxidant defense in the cell (detoxification of hydroperoxides) rely on the activity of glutathione peroxidase (GSH-Px), which in turn depends on adequate selenium status in the cell (Surai, 2000a,b). Indeed, a combination of dietary selenium supplementation with high vitamin $\mathrm{E}$ levels has been shown to further increase GSH-Px activity (Surai, 2000c). In particular, GSH-Px is involved in cellular antioxidant protection, and it has been suggested that GSH-Px works in synergy with vitamin $\mathrm{E}$, because GSH-Px continues the work of vitamin $\mathrm{E}$ by detoxifying hydroperoxides (Allan et al., 1999). This study was conducted to investigate the performance development, muscle n-3 and n-6 fatty acids, antioxidative status and immunological effects resulting from supplemented the flaxseed oil diets of growing $V$-line rabbits with lycopene and / or organic selenium (Sel-plex $\left.{ }^{\circledR}\right)$.

\section{MATERIALS AND METHODS}

Sixty growing V-line rabbits of both sexes, 5 weeks old, with initial weights of $781.0 \pm 23.85 \mathrm{~g}$ were used for the study during summer season (June- mid of August 2015). The rabbits were randomly allocated to five treatments groups of 12 rabbits each. Each treatment was further sub-divided into 4 replicates of 3 rabbits. Rabbits were housed in wire floor batteries of $45 \times 36 \times 36 \mathrm{~cm}$ and were offered diets for duration of the feeding trial until reaching 13 weeks of age. All rabbits were kept under similar hygienic conditions. Rabbits were housed in well ventilated block building. Fresh air circulated in the house using exhaust fans. The rabbits were kept within a cycle of $16 \mathrm{~h}$ light and $8 \mathrm{~h}$ dark. Five pelleted diets were prepared. Group I - fed a pelleted basal diet with standard components (control group), group II - fed a pelleted diet with $2 \%$ flaxseed oil, group III - fed a pelleted diet with $2 \%$ flaxseed oil and $0.25 \mathrm{mg} / \mathrm{kg}$ diet organic selenium Sel-plex, group IV fed a pelleted diet with $2 \%$ flaxseed oil and $110 \mathrm{mg}$ lycopene/ $\mathrm{kg}$ diet, group VI fed a pelleted diet with $2 \%$ flaxseed oil plus $0.25 \mathrm{mg} / \mathrm{kg}$ diet organic selenium Sel- 
plex® and $110 \mathrm{mg}$ lycopene/ $\mathrm{kg}$ diet. The experimental diets were feed for 8 weeks. Flaxseed oil was purchased from local company, (Alexandria company for extracted oils, Alexandria Governorate, Egypt), lycopene was purchased from Roche, Levent-Istanbul and Sel-plex®: a product produced by ALLTECH® (selenomethionine). Some modifications were done in the composition of the basal diets to make the five experimental diets isonitrogenous and isoenergetic containing approximately $17.0 \% \mathrm{CP}$ and $2542 \mathrm{Kcal} / \mathrm{kg}$ DE (Table. 1). Each group of rabbits was fed one of five experimental diets. Fresh water was automatically available at all times through stainless steel nipples for each cage. The experimental diets were offered to rabbits ad libitum.

Individual body weight and feed consumption were recorded weekly. Daily body weight gain and feed conversion ratio were also calculated. The incidence of dangerous diseases was largely avoided and rabbits have never been treated with any kind of systematic vaccination or medication. At the end of the feeding trial, 3 rabbits were selected from each treatment group randomly, starved of food but not water for 12 hours and slaughtered for carcass analysis. Before slaughtering, $6 \mathrm{ml}$ of blood sample was taken from the ear vein with a sterile syringe. $3 \mathrm{ml}$ of the blood was put into a bijon bottle containing ethylene diamine tetracetic acid (EDTA) as an anticoagulant for hematological assay. The remaining $3 \mathrm{ml}$ of the blood sample was put into a sterile vacutainer tube without an anticoagulant for serum biochemical analysis. The hematological assay was carried out to determine erythrocyte indices such as packed cell volume (PCV), and hemoglobin $(\mathrm{Hb})$ values. Red blood cell (RBC) counts were counted on an AO Bright line hemocytometer using a light microscope at 400X magnification (Natt and Herrick, 1952). White blood cell (WBC) counts according to Hepler (1966). Total lipids, triglycerides, cholesterol, low density lipoprotein (LDL) and high density lipoprotein (HDL), concentrations in serum were estimated using commercial kits (Bio Merieux, France) according to the procedure outlined by the manufacturer. Three rabbits of each treatment were immunized with $0.1 \mathrm{ml}$ of a $2.5 \%$ Sheep Red Blood Cells (SRBC) via the marginal ear vein at 15 days after starting the dietary treatment supplementation, to measure antibody titer against Sheep Red Blood Cells. The dosage of SRBC for inoculation was pre-determined by a separate trial. Antiserum to SRBC was collected 7, 14 and 21 days post challenge. One $\mathrm{ml}$ of blood was refrigerated to allow red blood cells to settle. If sedimentation was not complete, samples were centrifuged for 1 to $2 \mathrm{~min}$ at $3000 \mathrm{rpm}$ to separate plasma and erythrocytes, and the supernatant was collected. Briefly, 96-well plates were first filled with $50 \mu \mathrm{l}$ of physiological saline solution in each well. Then $50 \mu \mathrm{l}$ of antiserum was pipetted into the first well in duplicates after which $50 \mu l$ from the first well was pipetted into the second well, and so forth using an automatic pipette. Finally, a $0.75 \%$ of SRBC solution was added to each well. Plates were incubated at $37 \mathrm{o} \mathrm{C}$ for 3 hours and then examined visually for agglutination Wegmann and Smithies (1966). The agglutination titer was expressed as the log2 of the reciprocal of the highest serum dilution giving complete agglutination (Nelson et al., 1995). Fatty acids were extracted from hind leg muscle tissue of rabbit and analyzed by using gas chromatography (GLC) according to the method described by Radwan 
(1978). Muscle cholesterol was determined by method of Richmond (1973), by using "Cholesterol CHOD-PAP Kits" which produced by Human, Germany. The results were expressed as the mean \pm SEM. All data were analyzed using one way analysis of variance (ANOVA) using SPSS 11.0 statistical software (SPSS, Inc., Chicago, II, 2001). Significant differences between means were detected using new Duncan multiple range test (Duncan, 1955).

Table (1). Composition and chemical analyses of control and the basal flaxseed oil experimental diets.

\begin{tabular}{lcc}
\hline \multicolumn{1}{c}{ Ingredients } & Control & Linseed oil 2\% \\
\hline Clover hay & 28.00 & 28.00 \\
Yellow corn & 18.90 & 16.90 \\
Wheat bran & 11.00 & 11.00 \\
Barley grain & 17.30 & 17.30 \\
Soybean meal (44\%) & 20.00 & 20.00 \\
Molasses & 3.00 & 3.00 \\
Flaxseed oil & - & 2.00 \\
Limestone & 1.00 & 1.00 \\
Salt & 0.30 & 0.30 \\
DI- Methionine & 0.10 & 0.10 \\
L-Lysine & 0.10 & 0.10 \\
Vit, and min. mix. & 0.30 & 0.30 \\
\hline Total & 100 & 100 \\
\hline & Chemical analysis (\%) \\
\hline Crude Protein & 17.19 & \\
Crude Fiber & 12.44 & 17.04 \\
DE ${ }^{3}$ (Kcal / kg) (calculated) & 2542 & 2543 \\
\hline
\end{tabular}

${ }^{1}$ Vit+Min mixture provides per kilogram contains: Vit A $6000 \mathrm{IU}$; Vit $D_{3} 450$ IU; Vit E 40 mg; Vit $K_{3} 1 \mathrm{mg}$; Vit $B_{1} 1 \mathrm{mg}$; Vit $B_{2} 3 \mathrm{mg}$; Vit $B_{3} 180 \mathrm{mg}$; Vit $B_{6} 39 \mathrm{mg}$; Vit $\mathrm{B}_{12} 2.5 \mathrm{mg}$; Pantothenic acid $10 \mathrm{mg}$; biotin $10 \mathrm{mg}$; folic acid $2.5 \mathrm{mg}$; choline chloride 1200 mg; Manganese 15 mg; Zinc 35 mg; Iron 38 mg; Copper 5 mg; Selenium $0.1 \mathrm{mg}$; lodine $0.2 \mathrm{mg}$; Selenium $0.05 \mathrm{mg} .{ }^{2}$ Analyzed values according to AOAC (1995). DE calculated according to Fekete and Gippert (1986) as: DE $(\mathrm{kcal} / \mathrm{kg} \mathrm{DM})=4253$ - 32.6(Crude fibre \% DM) - 144.4(ash\% DM).

\section{RESULTS AND DISCUSSION}

The effects of flaxseed oil without or with organic selenium, lycopene and organic selenium plus lycopene on growth performance of growing rabbits are summarized in Table 2. The different experimental treatments had insignificant effect on daily body weight gain, feed intake and feed conversion ratio. However, it was observed numerical improvement in feed conversion ratio ranged from 11.4 to $16.7 \%$ due different experimental treatments in comparison with the control one. 
The best values of feed conversion ratio were recorded in the group given flaxseed oil with lycopene and the group given mix of flaxseed oil organic selenium with lycopene. These results were in agreement with those presented by Saleh et al. (2013) who showed that linseed oil has no significant effect on body weight, weight gain and feed intake of male growing New Zealand white rabbits, but feed intake was significantly reduced and feed conversion ratio was improved when linseed oil mixed with organic selenium. Furthermore, Trebušak et al. (2011) indicated that body weight gain was not influence when the rabbits fed on diets containing linseed oil, while feed intake was significantly reduced and feed conversion ratio improved. Jain et al. (1999) reported that live weight was not affected by lycopene supplementation in rat diets. In rabbits, treatment with lycopene and green tea extract did not negatively affect the performance characteristics of feed intake, body weight and feed conversion ratio (Tedesco et al., 2005). However, the results presented by Farag (2014) were in disagreement with our results, since He reported that 100, 200 and $300 \mathrm{mg}$ lycopene/ $\mathrm{kg}$ diet resulted in improving body weight gain and feed conversion ratio of growing chickens. Also, Zeweil et al. (2016) demonstrated that supplementation of 100 or $200 \mathrm{mg}$ lycopene / kg diet improved daily body weight gain and feed conversion ratio of growing rabbits.

\section{Table (2). Effects of flaxseed oil without or with organic selenium, lycopene and organic selenium plus lycopene on growth performance}

\begin{tabular}{|c|c|c|c|c|c|}
\hline Treatments & $\begin{array}{l}\text { Initialbody } \\
\text { weight (g) }\end{array}$ & $\begin{array}{l}\text { Final body } \\
\text { weight (g) }\end{array}$ & $\begin{array}{c}\text { Daily } \\
\text { weight gain } \\
\text { (g) }\end{array}$ & $\begin{array}{l}\text { Dailyfeed } \\
\text { intake (g) }\end{array}$ & $\begin{array}{c}\text { Feed } \\
\text { conversion } \\
\text { ratio(gfeed } \\
: \text { g gain) } \\
\end{array}$ \\
\hline Control & $785.1 \pm 12.9$ & $2327.5 \pm 17.9$ & $27.3 \pm 0.2$ & $72.3 \pm 2.6$ & $2.64 \pm 0.08$ \\
\hline Flaxseedoil 2\% & $788.7 \pm 9.5$ & $2377.5 \pm 19.8$ & $28.1 \pm 0.2$ & $65.96 \pm 3.3$ & $2.34 \pm 0.11$ \\
\hline Flaxseedoil $2 \%+S e(0.25 \mathrm{mg} / \mathrm{kg})$ & $783.2 \pm 9.0$ & $2365.6 \pm 17.8$ & $28.1 \pm 0.3$ & $64.84 \pm 1.9$ & $2.30 \pm 0.07$ \\
\hline Flaxseedoil 2\%+Lyco(110 mg/kg) & $779.2 \pm 12.7$ & $2341.0 \pm 8.5$ & $28.1 \pm 0.4$ & $62.1 \pm 2.2$ & $2.20 \pm 0.08$ \\
\hline Flaxseedoil $2 \%+S e(0.25 \mathrm{mg} / \mathrm{kg})+\mathrm{Lyco}(110 \mathrm{mg} / \mathrm{kg})$ & $780.0 \pm 14.9$ & $2344.0 \pm 8.9$ & $28.0 \pm 0.3$ & $63.8 \pm 3.1$ & $2.28 \pm 0.12$ \\
\hline
\end{tabular}

Results in table 3 for pre-slaughter weight and percentage of hot carcass and liver were insignificantly affected by different treatments in comparison with control. Different treatments significantly decrease the muscle total cholesterol but did not significantly effect on the abdominal fat weight, although it were lower in comparison with the control group. Salama (2011) reported that the linseed oil had insignificant effect on pre slaughter weight of rabbits at 13 weeks of age, however, the percentage of blood, dressing, heart and fur were significantly increased in comparison with control group. Abdulkareem (2011) found that addition of organic selenium at level $0.15 \mathrm{mg} / \mathrm{kg}$ diet resulted in significant $(p \leq 0.01)$ increase in dressed carcass percentage and significant $(p \leq 0.01)$ decrease in head percentage level of growing rabbits. Saleh et al. (2013) reported that carcass weight, dressing percentage and liver weight were increased; however, abdominal fat weight was decreased by dietary supplementation of linseed oil with organic selenium. Farag (2014) reported that the relative weight of carcass, gizzard, liver, spleen and tests 
were insignificantly affected by supplementation of 100 or $200 \mathrm{mg}$ lycopene / kg diet as compared with the control chickens. Also, Zeweil et al. (2016) found that 100 or 200 mg lycopene / kg of growing rabbit's diet had insignificant effect on all carcass traits.

Table (3). Effects of flaxseed oil without or with organic selenium, lycopene and organic selenium plus lycopene on carcass traits

\begin{tabular}{|c|c|c|c|c|c|}
\hline Treatments & $\begin{array}{c}\text { Pre- } \\
\text { slaughter } \\
\text { weight (g) }\end{array}$ & $\begin{array}{c}\text { Hot } \\
\text { carcass } \\
\%\end{array}$ & Liver \% & $\begin{array}{c}\text { Abdominal } \\
\text { fat weight } \\
\%\end{array}$ & $\begin{array}{c}\text { Muscle } \\
\text { total } \\
\text { cholesterol } \\
(\mathrm{mg} / \mathrm{dl})\end{array}$ \\
\hline Control & $2324.2 \pm 18.1$ & $55.1 \pm 1.1$ & $2.51 \pm 0.03$ & $2.45 \pm 0.19$ & $68.7 \pm 2.9^{b}$ \\
\hline Flaxseed oil $2 \%$ & $2377.5 \pm 21.7$ & $57.8 \pm 1.2$ & $2.53 \pm 0.09$ & $2.17 \pm 0.12$ & $57.0 \pm 2.1^{\mathrm{a}}$ \\
\hline Flaxseed oil $2 \%+S e(0.25 \mathrm{mg} / \mathrm{kg})$ & $2363.3 \pm 7.4$ & $56.7 \pm 0.6$ & $2.53 \pm 0.03$ & $1.91 \pm 0.14$ & $54.0 \pm 2.1^{\mathrm{a}}$ \\
\hline Flaxseed oil $2 \%+L y c o(110$ mg/kg) & $2341.0 \pm 13.8$ & $57.6 \pm 1.8$ & $2.53 \pm 0.05$ & $2.16 \pm 0.22$ & $54.7 \pm 2.6^{\mathrm{a}}$ \\
\hline Flaxseed oil $2 \%+$ Se $(0.25 \mathrm{mg} / \mathrm{kg})+\mathrm{Lyco}(110 \mathrm{mg} / \mathrm{kg})$ & $2344.0 \pm 14.2$ & $56.7 \pm 2.3$ & $2.53 \pm 0.05$ & $2.11 \pm 0.26$ & $54.3 \pm 1.9^{a}$ \\
\hline
\end{tabular}

Results illustrated in Table 4 showed the effects of flaxseed oil without or with organic selenium, lycopene and organic selenium plus lycopene on $n-3, n-6$ and the ratio $n-6 / n-3$ of the hind leg muscle fat. It was observed that the $n-3$ fatty acids were significantly ( $P \leq 0.05$ ) increased by feeding flaxseed oil, flaxseed oil plus organic selenium, flaxseed oil plus $110 \mathrm{mg}$ lycopene and mix of flaxseed oil plus organic selenium and $110 \mathrm{mg}$ lycopene treatment, while the $\mathrm{n}-6$ fatty acids were increased significantly by feeding flaxseed oil plus organic selenium, flaxseed oil plus $110 \mathrm{mg}$ lycopene and mix of flaxseed oil plus organic selenium and $110 \mathrm{mg}$ lycopene treatment.

These results suggest that the addition of flaxseed oil with organic selenium or lycopene could be recommendable to increase n-3 PUFA in rabbit meats, providing a healthier and functional rabbit meat to consumer. The best value was recorded in the group had flaxseed oil plus $110 \mathrm{mg}$ lycopene. The change of lipid composition of animal feeds can have an impact on the nutritional value of the meat consumed by the humans (Bourre, 2005). Feeding rabbits with pellet containing sunflower or linseed oil rich in PUFAs considerably improves polyunsaturated/saturated ratio, increases the $\alpha$-linolenic and linoleic level as well as increases the $n-3 / n-6$ ratio, an useful indicator for comparing relative nutritional values (Piggot et al., 1990), in the muscles (Zsédely et al., 2006). Trebušak et al., (2011) found that linoleic acid and $\alpha$-linolenic acid were increased while; palmatic acid was decreased when the rabbits fed on diet content linseed oil and consecutively caused a significant decrease in the n-6/n-3 PUFA ratio. Similarly, Peiretti (2012) reported that feeding rabbits with flaxseed oil, unsaturated fatty acids were increased and saturated fatty acids were decreased. 
Table (4). Effects of flaxseed oil without or with organic selenium, lycopene and organic selenium plus lycopene on composition of $n-3, n-6$ and the ratio $n-6 / n-3$ of the muscle tissue lipids in the rabbit hind leg ( $\mathrm{g}$ per $100 \mathrm{~g}$ of all acids determined)

\begin{tabular}{|c|c|c|c|}
\hline Treatments & $\begin{array}{c}n-3 \\
(m g / 100 g)\end{array}$ & $\begin{array}{c}n-6 \\
(m g / 100 g)\end{array}$ & $n-6 / n-3$ \\
\hline Control & $1.30 \pm 0.17^{\mathrm{d}}$ & $8.27 \pm 0.23^{b}$ & $6.65 \pm 1.10^{\mathrm{a}}$ \\
\hline Flaxseed & $3.57 \pm 0.32^{c}$ & $8.18 \pm 0.29^{b}$ & $2.32 \pm 0.14^{\mathrm{b}}$ \\
\hline Flaxseed oil $2 \%+\mathrm{Se}(0.25 n$ & $4.92 \pm 0.51^{\mathrm{b}}$ & $12.47 \pm 2.07^{\mathrm{a}}$ & $2.52 \pm 0.24^{\mathrm{a}}$ \\
\hline Flaxseed oil $2 \%+$ Lyco $(110 \mathrm{mg} / \mathrm{kg})$ & $6.53 \pm 0.32^{\mathrm{a}}$ & $12.43 \pm 0.37^{\mathrm{a}}$ & $1.91 \pm 0.06^{\mathrm{b}}$ \\
\hline Flaxseed oil $2 \%$ + Se $(0.25 \mathrm{mg} / \mathrm{kg})+\mathrm{Lyco}(110 \mathrm{mg} / \mathrm{kg})$ & $5.93 \pm 0.47^{\mathrm{ab}}$ & $11.73 \pm 0.67^{\mathrm{a}}$ & $2.01 \pm 0.23^{\mathrm{b}}$ \\
\hline
\end{tabular}

Different letters (a-d) within a column denote significant differences between treatments $(P \leq 0.05)$

Results on hematological parameters of the rabbits in Table 5 showed a general significant $(P \leq 0.05)$ increase in $P C V$, except flaxseed oil treatment and numerical increase in RBCs, WBCs, and $\mathrm{Hb}$ of rabbits fed flaxseed oil or diets containing flaxseed oil and supplemented with selenium, lycopene or selenium plus lycopene. Platlets was not differ significantly due to different treatments. The general increase in PCV and RBC of rabbits indicates that these feed additives may contain blood forming factors that may have stimulated more blood production by the rabbits fed supplemented diets than those fed control diet through summer season. This also suggests that these additives may have helped in boosting the immune system of the rabbits. The RBC, PCV and $\mathrm{Hb}$ values were fall within the normal range of $3.7-8.010^{6} \mu / \mathrm{I}, 25-50 \%$ and $8.9-17.5 \mathrm{~g} / \mathrm{dl}$ reported for healthy rabbits by Mitruka and Rawnsley (1977). The normal PCV indicates the absence of normocytic anemia which is reportedly characterized by normal MCV and $\mathrm{MCH}$ and only detected by a decreased number of RBCs or PCV (Coles, 1986). The result is corroborated by the normal RBCs which further elucidated the absence of hemolytic anemia and depression of erythrogenesis. The normal hemoglobin concentration for all the experimental rabbits is probably an indication that these feed additives supplement supported hemoglobin synthesis, which according to Sirosis (1995) is among other factors, primarily affected by protein intake. Njidda et al. (2006) reported that normal range of values for $\mathrm{Hb}$ indicated that the vital physiological relationship of hemoglobin with oxygen in the transport of gases (oxygen and carbon dioxide) to and from the tissues of the body has been maintained and was normal.

Antibody titters against SRBCs determined are shown in Table (6) as affected by flaxseed oil or the different feed additives in flaxseed oil diet in comparison with the control group free of flaxseed oil or feed additives. Different treatments did not increase antibody titters against SRBCs enough to find statistical significance, although it were higher in the most studied treatments compared with control group at 7, 14 and 21 days after vaccination. 
Table (5). Effects of flaxseed oil without or with organic selenium, lycopene and organic selenium plus lycopene on blood hematology

\begin{tabular}{|c|c|c|c|c|c|}
\hline Treatments & $\begin{array}{c}\text { RBCs } \\
\left(\times 10^{6} / \mathrm{mm}^{3}\right)\end{array}$ & $\begin{array}{c}\text { WBCs } \\
\left(\times 10^{3} / \mathrm{mm}^{3}\right)\end{array}$ & $\begin{array}{c}\mathrm{Hb} \\
\mathrm{mg} / \mathrm{dl}\end{array}$ & PCV\% & PLT \\
\hline Control & $4.50 \pm 0.30$ & $6.34 \pm 0.09$ & $11.48 \pm 0.74$ & $36.65 \pm 0.75^{c}$ & $229.00 \pm 3.79$ \\
\hline Flaxseed oil $2 \%$ & $5.55 \pm 0.20$ & $7.20 \pm 0.51$ & $12.45 \pm 0.78$ & $39.73 \pm 0.25^{\mathrm{bc}}$ & $220.33 \pm 2.91$ \\
\hline Flaxseed oil $2 \%$ + Se $(0.25 \mathrm{mg} / \mathrm{kg})$ & $5.32 \pm 0.34$ & $6.70 \pm 0.78$ & $11.95 \pm 0.49$ & $41.75 \pm 0.91^{\mathrm{ab}}$ & $222.67 \pm 3.93$ \\
\hline Flaxseed oil $2 \%$ +Lyco (110 mg/kg) & $5.54 \pm 0.24$ & $6.20 \pm 1.24$ & $11.95 \pm 0.62$ & $42.85 \pm 1.52^{\mathrm{ab}}$ & $219.25 \pm 1.70$ \\
\hline Flaxseed oil $2 \%+$ Se $(0.25 \mathrm{mg} / \mathrm{kg})+$ Lyco $(110 \mathrm{mg} / \mathrm{kg})$ & $5.50 \pm 0.24$ & $8.16 \pm 0.41$ & $12.27 \pm 0.17$ & $44.01 \pm 0.65^{\mathrm{a}}$ & $218.75 \pm 4.48$ \\
\hline
\end{tabular}

Different letters (a-c) within a column denote significant differences between treatments $(P \leq 0.05)$

Table (6). Effects of flaxseed oil without or with organic selenium, lycopene and organic selenium plus lycopene on antibody titer (log2)

\begin{tabular}{lccc}
\hline \multicolumn{1}{c}{ Treatments } & 14 days & 21 days & 28 days \\
\hline Control & $0.89 \pm 0.03$ & $0.93 \pm 0.03$ & $0.82 \pm 0.05$ \\
Flaxseed oil $2 \%$ & $0.89 \pm 0.01$ & $0.93 \pm 0.04$ & $0.83 \pm 0.06$ \\
Flaxseed oil $2 \%+$ Se $(0.25 \mathrm{mg} / \mathrm{kg})$ & $0.91 \pm 0.03$ & $0.94 \pm 0.05$ & $0.87 \pm 0.04$ \\
Flaxseed oil $2 \%+$ Lyco $(110 \mathrm{mg} / \mathrm{kg})$ & $0.94 \pm 0.03$ & $0.94 \pm 0.04$ & $0.86 \pm 0.06$ \\
Flaxseed oil $2 \%+$ Se $(0.25 \mathrm{mg} / \mathrm{kg})+$ Lyco $(110 \mathrm{mg} / \mathrm{kg})$ & $0.94 \pm 0.02$ & $0.95 \pm 0.03$ & $0.88 \pm 0.04$ \\
\hline
\end{tabular}

Results illustrated in Table 7 showed the effect of different treatments on blood serum lipid profile. It was observed that serum total lipids, total cholesterol and low density lipoprotein significantly $(P \leq 0.05)$ decreased due to different experimental diets in comparison with the control group, however, triglycerides numerically decreased due to different treatments. On the other hand, high density lipoprotein concentration and HDL/LDL ratio were significantly $(P \leq 0.05)$ increased by different experimental diets as compared with the control group. Salama (2011) found that plasma cholesterol and triglycerides levels were decreased significantly in rabbits fed $2 \%$ linseed oil followed by $2 \%$ linseed oil plus $0.5 \%$ green tea and $0.5 \%$ green tea diets relative to control diet. On the other hand, high density lipoprotein cholesterol (HDL-chol) were significantly $(P \leq 0.05)$ increased by supplementing $2 \%$ linseed oil and $2 \%$ linseed oil plus $0.5 \%$ green tea as compared to the other treatments followed by those supplementing $0.5 \%$ green tea, increases in mean plasma total and high-density lipoprotein cholesterol concentrations. But low-density lipoprotein cholesterol (LDL-chol) was not significantly affected by supplementing $2 \%$ linseed oil or $0.5 \%$ green tea and control group. Also, Saleh et al. (2013) showed that dietary supplementation of linseed oil with or without organic selenium decreased plasma total cholesterol and LDL, while, plasma HDL and glutathione peroxidase were increased in linseed oil plus organic selenium. This effect might be attributed to the lipolysis which was increased by selenium feeding (Miezeliene et al., 2011). Zeweil et al. (2016) showed that serum total lipids, total cholesterol and triglycerides were significantly $(P \leq 0.01)$ reduced due to addition of 100 or $200 \mathrm{mg}$ lycopene in growing rabbit diets in comparison with the control group. 
Exposing growing rabbits to high temperature conditions during summer season resulted in significant decrease $(P \leq 0.001)$ in serum total antioxidant capacity and elevated $(P \leq 0.05)$ serum MDA which was obtained in the control group, however, including flaxseed oil or flaxseed oil plus different feed additives used in the present study appeared to antagonize the effect of high temperature during summer (Table 8). The total antioxidant capacity in blood serum of rabbits fed flaxseed oil, flaxseed oil plus selenium, linseed oil plus $110 \mathrm{mg}$ lycopene $/ \mathrm{kg}$ diet and combined of flaxseed oil plus selenium and $110 \mathrm{mg}$ lycopene increased its value by about $12.1,12.1,7.7$ and $9.9 \%$, respectively, as compared with the control group. However, these treatments reduced lipid peroxidation in serum expressed as serum malondialdehyde (MDA) by 35.0, 32.2, 33.4 and $26.9 \%$, respectively, in comparison with the control one free of flaxseed oil and different feed additives.

Heat stress through summer conditions causes increased free radical production (Halliwell and Gutteridge, 1989) and lowers the concentrations of antioxidant vitamins and minerals such as E, C, A and $\mathrm{Zn}$ in serum and tissues (Sahin and Kucuk, 2003). Free radicals trigger the metabolic disorder, cell death and growth retardation (Okada, 1996). Salama (2011) showed that dietary treatment with $2 \%$ linseed oil and/ or $0.5 \%$ green tea significantly increased total antioxidant capacity, superoxide dismutase and glutathion peroxidase activity, however, MDA concentration was significantly reduced comparing to the control group. Also, Abdulkareem (2011) proved that different levels of dietary organic selenium showed a positive effect on antioxidative properties as measured by total antioxidant capacity when compared with control $(P \leq 0.05)$. Fattening rabbits fed $0.3 \mathrm{ppm}$ organic selenium had the highest total antioxidant capacity value in blood plasma $(2.02 \mathrm{mg} / \mathrm{dl})$ compared with control $(1.30 \mathrm{mg} / \mathrm{dl})$. Also, the authors observed that plasma TBARS values were decreased insignificantly when fattening rabbits fed organic selenium. Zeweil et al. (2016) showed that exposing growing rabbits to high temperature conditions during summer season resulted in significant decrease $(P \leq 0.05)$ in serum total antioxidant capacity which was obtained in the control group, however, supplementation of 100 or $200 \mathrm{mg}$ lycopene / kg of growing rabbit diets appeared to antagonize the effect of high temperature. The different levels of lycopene (100 and $200 \mathrm{mg}$ ) increased total antioxidant capacity in blood serum to rich an increase their value by 51.9 and $49.4 \%$, respectively, in comparison with the control group. In conclusion, the addition of flaxseed oil with organic selenium or lycopene could be recommendable to increase n-3 PUFA in rabbit meats, providing a healthier and functional rabbit meat to consumer. 
Table (7). Effects of flaxseed oil without or with organic selenium, lycopene and organic selenium plus lycopene on blood serum lipid profile

\begin{tabular}{|c|c|c|c|c|c|c|}
\hline Treatments & $\begin{array}{c}\text { Total } \\
\text { lipids } \\
\text { (mg/dl) }\end{array}$ & $\begin{array}{l}\text { Trigly- } \\
\text { cerides } \\
\text { (mg/dl) }\end{array}$ & $\begin{array}{c}\text { Total } \\
\text { cholesterol } \\
\text { (mg/dl) }\end{array}$ & $\begin{array}{l}\text { HDL } \\
\text { (mg/dl) }\end{array}$ & $\begin{array}{c}\text { LDL } \\
\text { (mg/dl) }\end{array}$ & HDL/LDL \\
\hline Control & $375.5 \pm 8.6^{\mathrm{a}}$ & $70.4 \pm 4.4$ & $69.4 \pm 2.1^{\mathrm{a}}$ & $21.9 \pm 1.3^{b}$ & $20.8 \pm 0.4^{a}$ & $1.1 \pm 0.08^{b}$ \\
\hline Flaxseed oil $2 \%$ & $346.5 \pm 10.1^{\mathrm{ab}}$ & $63.0 \pm 16.0$ & $60.4 \pm 3.3^{b c}$ & $27.1 \pm 1.0^{\mathrm{a}}$ & $17.3 \pm 0.2^{b}$ & $1.6 \pm 0.07^{\mathrm{a}}$ \\
\hline Flaxseed oil $2 \%$ + Se $(0.25 \mathrm{mg} / \mathrm{kg})$ & $330.3 \pm 2.9^{b}$ & $60.3 \pm 1.8$ & $56.0 \pm 3.0^{c}$ & $27.4 \pm 0.9^{\mathrm{a}}$ & $18.3 \pm 0.6^{b}$ & $1.5 \pm 0.11^{\mathrm{a}}$ \\
\hline Flaxseed oil 2\% +Lyco (110 mg/kg) & $328.1 \pm 19.4^{b}$ & $64.1 \pm 2.2$ & $61.5 \pm 3.2^{\mathrm{abc}}$ & $27.2 \pm 0.6^{\mathrm{a}}$ & $17.8 \pm 0.3^{\mathrm{b}}$ & $1.5 \pm 0.04^{\mathrm{a}}$ \\
\hline Flaxseed oil $2 \%+\operatorname{Se}(0.25 \mathrm{mg} / \mathrm{kg})+$ Lyco $(110 \mathrm{mg} / \mathrm{kg})$ & $327.3 \pm 6.8^{\mathrm{b}}$ & $65.1 \pm 3.7$ & $67.8 \pm 1.6^{\mathrm{ab}}$ & $26.7 \pm 0.9^{\mathrm{a}}$ & $17.9 \pm 0.5^{\mathrm{b}}$ & $1.5 \pm 0.07^{\mathrm{a}}$ \\
\hline
\end{tabular}

Table (8). Effects of flaxseed oil without or with organic selenium, lycopene and organic selenium plus lycopene on blood serum lipid profile

\begin{tabular}{lcc}
\hline \multicolumn{1}{c}{ Treatments } & $\begin{array}{c}\text { Total } \\
\text { antioxidant } \\
\text { capacity }(\mathbf{m M} / \mathrm{L})\end{array}$ & $\begin{array}{c}\text { Malondialdehyde } \\
(\mathbf{n m o l} / \mathbf{m l})\end{array}$ \\
\hline Control & $0.91 \pm 0.01^{\mathrm{b}}$ & $6.43 \pm 0.65^{\mathrm{a}}$ \\
Flaxseed oil 2\% & $1.02 \pm 0.03^{\mathrm{a}}$ & $4.18 \pm 0.53^{\mathrm{b}}$ \\
Flaxseed oil 2\% + Se $(0.25 \mathrm{mg} / \mathrm{kg})$ & $1.02 \pm 0.04^{\mathrm{a}}$ & $4.36 \pm 0.54^{\mathrm{b}}$ \\
Flaxseed oil 2\% +Lyco $(110 \mathrm{mg} / \mathrm{kg})$ & $0.98 \pm 0.03^{\mathrm{ab}}$ & $4.28 \pm 0.15^{\mathrm{b}}$ \\
Flaxseed oil 2\% + Se $(0.25 \mathrm{mg} / \mathrm{kg})+$ Lyco $(110 \mathrm{mg} / \mathrm{kg})$ & $1.00 \pm 0.01^{\mathrm{ab}}$ & $4.70 \pm 0.41^{\mathrm{b}}$ \\
\hline
\end{tabular}

Different letters $(a-b)$ within a column denote significant differences between treatments $(P \leq 0.05)$

\section{REFERENCES}

A.O.A.C. (1995). Official methods of Analysis $16^{\text {th }}$ Edition Association of official Analytical chemists. Washington D.C.

Abdulkareem, Hanan B. G. (2011). Studies on the fortification of rabbit meat with organic Selenium and vitamin $\mathrm{E}$ and their effects on antioxidative status and immune response in growing rabbits. M. Sc. Thesis, Fac. Agric. (Sabab Basha), Alexandria University, Egypt.

Allan, C.B., G.M.Lacourciere and T. C. Stadtman (1999). Responsiveness of selenoproteins to dietary selenium. Annu. Rev. Nutr., 19: 1-16.

Bourre, J. M. (2005). Effect of increasing the omega-3 fatty acid in the diets of animals on the animal products consumed by humans. Med. Sci. (Paris), 21: 773-779.

Budin, J. T., W.M. Breene and D. H. Putman (1995). Some compositional properties of Camelina (Camelina sativa L. Cratz) seed and oil. J.Am. Oil Chem. Soc., 72:309-315.

Coles, E.H. (1986). Erythrocytes. In: Veterinary clinical pathology, 2nd ed. Saundal WB. Company, Philadelphia, London, Toronto. pp. 99-141.

Duncan, D.B. (1955). Multiple ranges and multiple f-test, Biometries 11: 1-42. 
Farag, M. E. E. (2014). Effect of supplementation of some extracts of phytochemicals on the productive performance and carcass traits for Gimmizah chickens strain. Ph. D thesis, Fac. Agric. (Saba Basha), Alexandria University, Egypt.

Fekete, S. and T. Gippert (1986). Digestibility and nutritive value of nineteen important feedstuffs for rabbits. J. Appl. Rabbit Res., (9): 103-108.

Flachowsky, G., T. Langbein, H. Bohme, A. Schnieder and K. Aulrich (1998). Effect of flax expeller combined with short-term vitamin $E$ supplementation in pigs feeding on the fatty acid pattern, vitamin E tissues. J. Anim. Physiol. Anim. Nutr., 78:187-195.

Halliwell, B.E and J. M. C. Gutteridge (1989). Lipid peroxidation: a radical chain reaction. In: Free Radicals in Biology and Medicine, 2nd ed. Oxford University Press, New York, NY, pp. 188-218.

Hepler, O. E. (1966). Manual of Clinical Laboratory Methods. Thomas Spring Field. Illinois.

Jain, C.K., S. Agarwal and A.V. Rao (1999). The effect of dietary lycopene on bioavailability, tissue distribution, in-vivo antioxidant properties and colonic preneoplasia in rats. Nutr. Res., 19:1383-1391.

Marković, K., M. Hruškar and N. Vahčić (2006). Lycopene content of tomato products and their contribution to the lycopene intake of Croatians. Nutrition Research, 26: 556-560.

Miezeliene, A., G. Alencikiene, R. Gruzauskas and T. Barstys (2011). The effect of dietary selenium supplementation on meat quality of broiler chickens. Biotechnol Agron Soc Environ, 15(S): 61-69.

Mitruka, B.M. and H.M .Rawnsley (1977). Clinical biochemical and hematological reference values in normal experimental animals. Masson Publ. Co. New York, pp. 102-117.

Natt, M. P. and C. A. Herrick (1952). A new blood diluent for counting erythrocytes and leucocytes of the chicken. Poultry Science, 31: 735-738.

Nelson N.A., Lakshmanan N., Lamont S. J. (1995). Sheep red blood cell and Brucella abortus antibody responses in chickens selected for multitrait immunocompetence. Poultry Sci., 74:1603-1609.

Njidda, A. A., Igwebuike, J. U. and C. E .Isidahomen (2006). Haematological Parameters and carcass characteristics of weaning rabbits fed grade levels of molasses. Global Journal of Agric. Sci., 5(7): 167-172.

Okada, S. (1996). Iron-induced tissue damage and cancer: the role of reactive oxygen species-free radicals. Pathology International, 46: 311-332.

Peiretti, P. G. (2012). Effects of dietary fatty acids on lipid traits in the muscle and perirenal fat of growing rabbits fed mixed diets. Animals, 2: 55-67.

Piggot, G.M and B.W. Tucker (1990). Sea Foods: Effects of technology on nutrition. Marcel Dekker Inc, New York.

Radwan, S. S. (1978). Coupling of two dimensional thin layer chromatography with gas chromatography of the quantitative analysis of lipids classed and their constituent fatty acids. J Chromatogr Sci, 16: 538-542. 
Richmond, W. (1973). Preparation and properties of cholesterol oxidase from Nocardia spAnd application to the enzymatic assay of total cholesterol in serum. Clin Chem, 19: 1350-1356.

Sahin, K. and O. Kucuk (2003). Heat stress and dietary vitamin supplementation of poultry diets. Nutr. Abstr. Rev. Ser. B Livest. Feed Feeding 73, 41R-50R.

Salama, Maha F. A. (2011). Studies on the possibility of producing n-3 enriched rabbit meat. M. Sc. Thesis, Fac. Agric. (Saba Basha), Alexandria University, Egypt.

Saleh, A., T. A. Ebeid and Y. Z. Eid (2013). The Effect of Dietary Linseed Oil and Organic Selenium on Growth Performance and Muscle Fatty Acids in Growing Rabbits. Pak Vet J, 33(4): 450-454.

Schuster, A and W. Friedt (1998). Glucosinolate content and composition as parameters of quality of Camelini seed. Ind. Crop Prod, 7:297-302.

Ševčíková, S., M. Skřivan and G. Dlouhá (2008). The effect of lycopene supplementation on lipid profile and meat quality of broiler chickens. Czech Journal of Animal Science, 53, 431-440.

Sirosis, M. (1995). Veterinary clinical laboratory procedure. Mosby year book, Inc. St. Louis, Missouri, USA.

SPSS Statistical Packages for the Social Sciences, (2001). Statiatical software for windows version 11.0 Microsoft. SPSS ${ }^{\circledR}$, Chicago, IL, USA.

Surai, P.F. (2000a). Effect of the selenium and vitamin E content of the maternal diet on the antioxidant system of the yolk and the developing chick. British Poultry Science 41: 235-243.

Surai, P.F. (2000b). Organic selenium and the agg: Lessons from nature. Feed Compounder 20: 16-18.

Surai, P.F. (2000c). Organic selenium : benefits to animals and humans, a biochemist's view. Ln: Biotechnology in the feed industry. Proceedings of Alltech's $16^{\text {th }}$ Annual Symposium (Lyons T.P. and J acques K.A., eds.) Nottingham University Press. Nottingham, UK, pp.205-260.

Tedesco, D., S. Galletti, S. Rossetti and P. Morazzoni (2005). Dietary tea catechins and lycopene: effects on meat lipid oxidation. In: Indicators of milk and beef quality, EAAP Publication, No. 112, 437-442.

Trebušak, T., A. Levart, M. Voljč, U. Tomažin and T. Pirman (2011). The effect of linseed oil supplementation on performance, fatty acid composition and oxidative stat us of rabbits. Acta Argic Slovenica, 98: 119-125.

Wegmann, T.G. and O. Smithies (1966). A simple hemagglutination system requiring small amount of red cells and antibodies. Transfusion, 6: 67-73.

Zeweil, H. S. , S. M. Zahran, M. H. Ahmed, Y. El- El-Gindy and W. G. M. Shaglouf. (2016). Effects of allicin and lycopene on performance, carcass, hematological profile and antioxidant status of growing rabbits through summer season. Journal of the Advances in Agriculture Research, (Under publication). 
Zsédely, E., T. Tóth, C. Eiben, G. Tobias, S. Godor, B. Vegi, G. Virág and J. Schmidt (2006). Influence of sunflower and linseed oil supplementation of rabbit feed. 2. Composition and fatty acids profile of the meat and liver of rabbits. In: 18. Nyúltenyésztési Tudományos Nap, Kaposvár, 59-65.

الملخص العربي

تأثير كلا من السلينيوم العضوى والليكويبن المضاف الى عليقة الأرانب المحتوية على زيت الكتان على الأداء الانتاجى، الأبيحة ، ومحتوى العضلات من اوميجا ب،7، ودهون الام والحالة الضد تأكسدية فى الأرانب

حسن صابر زويل وسليمان محمد زهران ومحمد حسن أحمد وياسمين مؤمن الجندي وعلى محمد ابويكر لفطح

قسم الإنتاج الحيواني والسمكي - كلية الزراعة ( سابا باثا ) جامعة الإسكندرية

تهدف هذه الدراسة الى بحث تأثثر كلا من السلينيوم العضوى والليكوبين المضاف الى عليقة الأرانب الدحتوية على

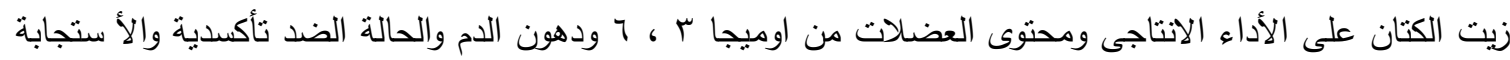

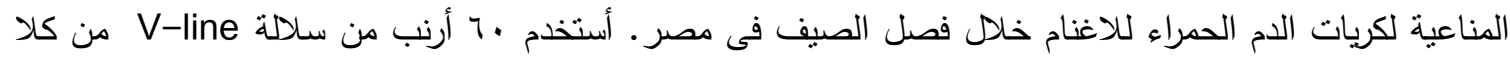

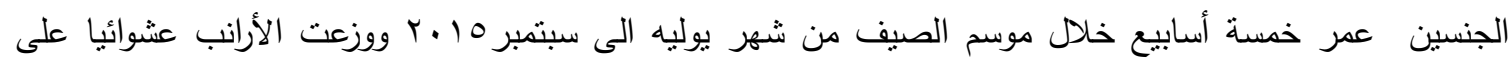
خمسة معاملات وبكل معاملة ب أرنب. وبكل معاملة گ مكررات وبكل مكررة ب أرانب. المجموعة الأولى تتاولت عليقة

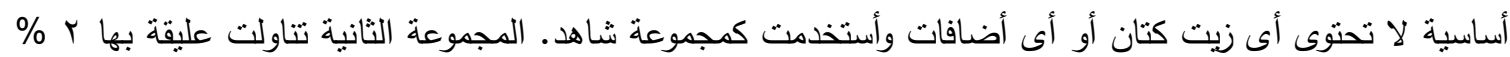

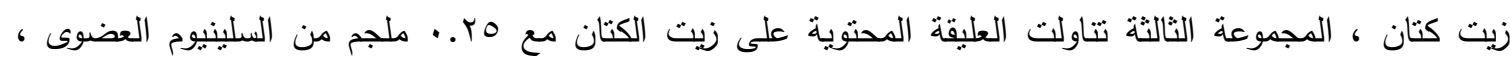

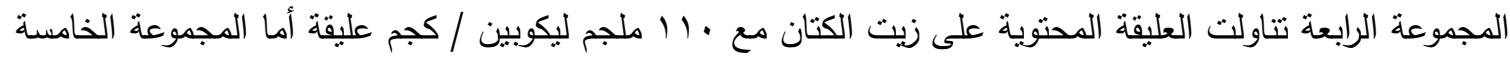

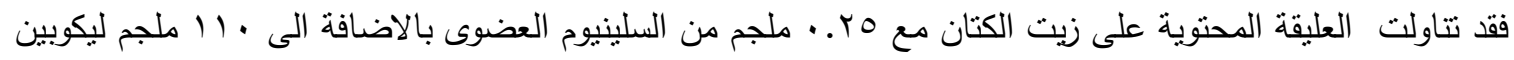
/كجم عليقة. أوضحت النتائج أن المعاملات المختلفة لم يكن لها أى تأثير على وزن الجسم المكتسب ، أستهلالك العليقة ، الكفاءة التحويلية ، وصفات الذبيحة. نلاحظ زيادة الأوميجا ب نتيجة لاحتواء العليقة على زيت الكتان ، زيت الكتان

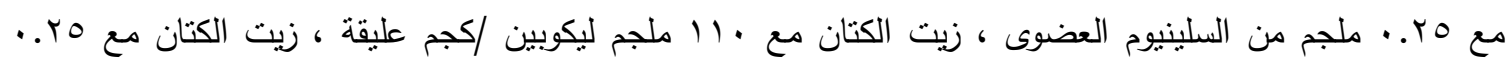

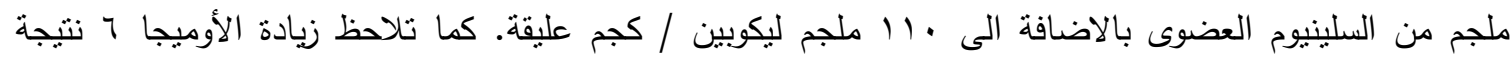

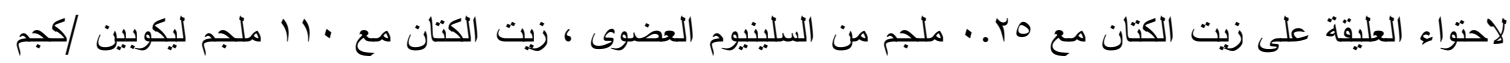

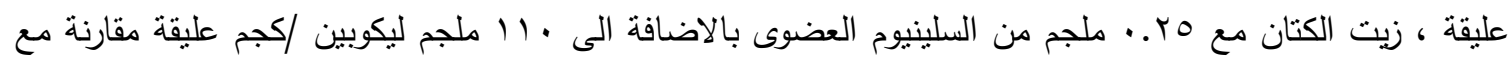
مجموعة الثاهد بينما لوحظ زيادة معنوية فى الكولسترول مرتفع الكثافة والنسبة بين الكولسترول مرتفع الكثافة الى لى 
الكولسترول منخفض الكثافة نتيجة لجميع الاضافات المستخدمة. وجد أن تعرض الأرانب للحرارة المرتفعة خلال فصل

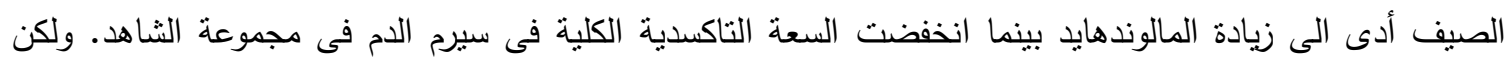

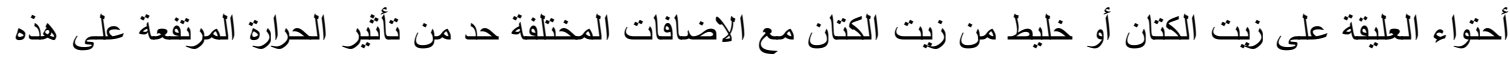
الصفات خلال فصل الصيف.

وتوصي الدراسة بتغذية الارانب النامية تحت الظروف الحارة للبيئة المصرية على زيت بذرة الكتان مع

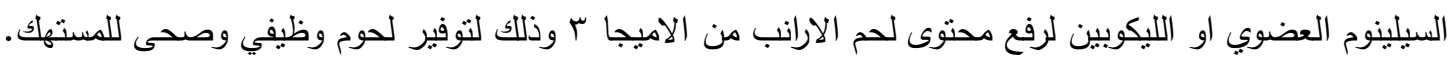

